\title{
Ward councillors' leadership characteristics and their impact on service delivery: Case of eThekwini Metropolitan Municipality, South Africa, in 2018
}

\begin{tabular}{|c|c|}
\hline $\begin{array}{l}\text { Authors: } \\
\text { Zamokuhle M } \\
\text { Syden Mishi² }\end{array}$ & oandlwa ${ }^{1}$ (1) \\
\hline $\begin{array}{l}\text { Affiliations: } \\
{ }^{1} \text { Department } \\
\text { Durban Unive } \\
\text { Technology, D } \\
\text { South Africa }\end{array}$ & $\begin{array}{l}\text { f Economics, } \\
\text { sity of } \\
\text { urban, }\end{array}$ \\
\hline $\begin{array}{l}\text { 2Department } \\
\text { Management, } \\
\text { Mandela Univ } \\
\text { Elizabeth, Sou }\end{array}$ & $\begin{array}{l}\text { f Public } \\
\text { Nelson } \\
\text { ersity, Port } \\
\text { th Africa }\end{array}$ \\
\hline $\begin{array}{l}\text { Correspondin } \\
\text { Zamokuhle M } \\
\text { 21240964@d }\end{array}$ & $\begin{array}{l}\text { g author: } \\
\text { oandlwa, } \\
\text { t4life.ac.za }\end{array}$ \\
\hline $\begin{array}{l}\text { Dates: } \\
\text { Received: } 09 \text { 」 } \\
\text { Accepted: } 06 \\
\text { Published: } 03\end{array}$ & $\begin{array}{l}\text { uly } 2019 \\
\text { Pec. } 2019 \\
\text { Feb. } 2020\end{array}$ \\
\hline $\begin{array}{l}\text { How to cite th } \\
\text { Mbandlwa, Z. } \\
\text { 2020, 'Ward c } \\
\text { leadership ch } \\
\text { and their imp } \\
\text { delivery: Case } \\
\text { Metropolitan } \\
\text { South Africa, i } \\
\text { Journal of Loc } \\
\text { Research and } \\
\text { a5. https://do } \\
\text { jolgri.v1i0.5 }\end{array}$ & $\begin{array}{l}\text { is article: } \\
\text { \& Mishi, S., } \\
\text { ouncillors' } \\
\text { racteristics } \\
\text { act on service } \\
\text { of eThekwini } \\
\text { Municipality, } \\
\text { n 2018', } \\
\text { al Government } \\
\text { Innovation 1(0), } \\
\text { i.org/10.4102/ }\end{array}$ \\
\hline $\begin{array}{l}\text { Copyright: } \\
\text { (c) 2020. The } \\
\text { Licensee: AOS } \\
\text { is licensed un } \\
\text { Creative Comr } \\
\text { Attribution Lic }\end{array}$ & $\begin{array}{l}\text { uthors. } \\
\text { S. This work } \\
\text { ler the } \\
\text { nons } \\
\text { ense. }\end{array}$ \\
\hline Read online: & \\
\hline 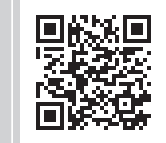 & $\begin{array}{l}\text { Scan this QR } \\
\text { code with your } \\
\text { smart phone or } \\
\text { mobile device } \\
\text { to read online. }\end{array}$ \\
\hline
\end{tabular}

Background: A municipality is considered as the first level of government that is closer to the people and is expected to deliver to the needs of the people. Political leadership is provided by elected ward councillors with the responsibility of delivering the public services at the local government level and also entrusted with control of the resources of local government.

Aim: The aim of this article was to evaluate the leadership characteristics of ward councillors and determine how such characteristics influence public service delivery in the eThekwini Municipality.

Setting: The individual leadership characteristics of ward councillors contribute to how decisions are made at the local government level and eThekwini Metropolitan Municipality as the third largest metropolitan municipality in the country is viewed as a strategic municipality.

Methods: This article adopted the form of a descriptive case study which employed a mixedmethods approach, using qualitative and quantitative methods for data collection and analysis. The study found that the leadership rating score, education and experience are key factors in good leadership (experienced less or no service delivery protest). A regression variable plot was used to analyse community members' responses on rating each ward councillor.

Results: The results show that lower levels of leadership characteristics are marred by numerous service delivery protests, and leadership characteristics increase chances of getting service delivery response albeit taking a U-shape.

Conclusion: It is recommended that ward councillors undergo a background check and enrol for leadership training programmes immediately when they are elected as ward councillors.

Keywords: leadership; characteristics; politics; challenges; principles; governance.

\section{Introduction}

Leadership shapes institutions and, as a result, the development of societies. Understanding challenges bedevilling societies and finding solutions to the challenges require an understanding of the characteristics of those in leadership. Assessing leadership characteristics is crucial in any society or institutional set-up because leaders are strongly affected by their character. Ward councillors are supposed to be the exemplary individuals in a society, and it is important to have councillors who have necessary leadership characteristics. Sharma and Rai (2003:393) argued that past research has shown that leadership characteristics have a direct influence on individual performance in leadership.

Today's society is marred by social ills of corruption, nepotism, theft, bribery, murder and lack of adequate service delivery commensurate with the societal needs of employment, poverty eradication and inequality reduction, amongst others. The phenomenon is across the globe, with the source of such pointing towards the character of those in leadership (Gupta \& Van Wart 2015: 5). South Africa is not an exception to this and has had a significant share of the problems which result in service delivery protests (Drennan, McConnell \& Stark 2014:8) as well as politically motivated killings (Du Toit \& Manganyi 2016:34). It is at this backdrop that this article investigates the leadership characteristics of ward councillors in one of the eight metropolitans in South Africa (i.e. eThekwini Municipality, the third largest municipality after the City of Cape Town) (StatSA 2011). This metropolitan municipality is home to the majority of politically motivated killings in the recent past (De Haas 2016: 43). This study hypothesises that 
with councillors having the right leadership characteristics in general and considered so in the eyes of the community, strong inter-relationships will be built and utilised for the development of the society. However, it has been observed that councillors sometimes fail to protect community members who are not interested in embarking on a protest, and ward councillors fail to play their inter-relationshipbuilding role between the municipality and the community (Thornhill \& Dlamini 2012:38).

A study conducted by the Institute of Security Studies (ISS 2014:15) showed that the public protests in many communities across South Africa are related to the leadership (or lack of it) of ward councillors, especially concerning their leadership characteristics and their role in service delivery. The ISS recorded that two-thirds of protests have been violent and mainly in the metropolitan areas. Public protests have the potential of turning into a revolution as this problem is linked with the frustrations of empty promises of service delivery or the failure of ward councillors to provide an effective leadership role (Hough 2008:08). Councillors have the authority over community government programmes and are in a position to gather information around the aspirations of society and community to the government for programmes and policy development. Their efficacy as leaders is therefore of paramount importance. Afegbua and Adejuwon (2012:141) suggested that most African countries are suffering from politico-economic crises, and the problems are caused by the political, social and economic instability in our societies. This seems to have resulted in leaders perceiving that being in leadership assists them to improve their lives economically. Low levels of accountability of African leaders in many African countries have resulted in political instability and violence. It is imperative to note that a leader's popularity rests on how the society he or she is leading perceives him or her: this is so because people under the leadership choose reaction (protest or support) depending on how they perceive their leaders as making effort towards helping the society to develop.

The aim of this study was to assess ward councillors' leadership characteristics and their impact on service delivery use - a case of eThekwini Municipality, KwaZuluNatal province, South Africa. eThekwini is the third largest metropolitan municipality, in terms of population size based on census data, after the City of Johannesburg in Gauteng with 4434827 people and the City of Cape Town in Western Cape province with 3740026 people. Our study area, eThekwini, KwaZulu-Natal, has a population of 3442361 people. The specific objectives of the study are as the following:

- to examine the leadership characteristics of ward councillors in eThekwini Municipality

- to identify the factors that hinder ward councillors' leadership performance on their duties in eThekwini Municipality

- to determine the impact of ward councillors' leadership skills on service delivery
- to suggest steps that can be followed to improve the leadership of ward councillors in eThekwini Municipality.

\section{Research questions}

The primary research question for this study is as follows: what is the ward councillor's leadership style and what is its effect on service delivery?

The sub-questions are as follows:

- What are the common leadership characteristics amongst ward councillors in eThekwini Municipality?

- What factors affect ward councillors to successfully do their jobs and provide effective leadership?

- What impact do the leadership characteristics of ward councillors have on the process of service delivery?

- What steps can be followed to improve the leadership skills of ward councillors?

\section{Background to local government leadership and service delivery in local government level}

South Africa has a history of colonialism, with a segregatory system of apartheid. The systems that have been used in local government level have changed over recent years in an effort to undo the past injustices. On the contrary, culture, power and gender politics has been affecting the local leadership and the service delivery in almost all the local governments or municipalities. Culture, gender and power battle affects service delivery because in some cases programme officers or partners in local government are concerned that promotion of gender equality would interfere with local culture and therefore feel that gender equality should not be promoted for ethical reasons. In other cases, the cultural values of a particular area are described as a major constraint on efforts for gender equality, and therefore, action is considered to be difficult for practical reasons (Gender Development 2017:03).

Morell, Jewkes and Lindegger (2012:17) state that the apartheid era has created a certain perception about who must be in leadership of government and the attributes required from leaders. Apartheid government did not create equal opportunities for men and women, and government positions were categorised according to the gender of individuals. Local government leaders were the eyes of the people in the local government in terms of ensuring that all public funds are used effectively; however, services were not delivered equally to the societies because of race segregation. In correcting such past injustices requires leadership that is upright and possesses good characteristics. There has been criticism regarding the cadre deployment focus at the expense of communities that are to be led. In that regard, attributes of good leaders may be ignored at the expense of service delivery.

The framework of the local government level requires special skills and expertise because the local government 
is the legally established institution entrusted with the responsibility to deliver services to the people. Institutions take the form of the elected council representing the municipality, and each ward is represented by a ward councillor (Bratton 2012:517). Institutions are strong and effective in relation to strength and effectiveness of those elected into leadership positions.

Afegbua and Adejuwon (2012:141) suggested that most African countries are suffering from politico-economic crises, and the problems are caused by the political, social and economic instability in our societies. This seems to have resulted in leaders perceiving that being in leadership position assists them to improve their lives economically. Low levels of accountability of African leaders in many African countries have resulted in political instability and violence.

In South Africa, local government (which is also known as the council) is responsible for handling community needs, such as waste collection, public recreation facilities, and town planning and infrastructure development. A related structure is that of Australia, with their policy (Australian Gazette 2015:144) stating that the Government of Australia has categorised the local government levels into cities, shires, towns or municipalities; however, the role and the manner in which leadership is elected are the same, and this type of government level requires a high level of discipline. Generally, local governments are mandated to solve the problems of the local community, but it has been discovered that there is a lack of good leadership characteristics amongst the local leadership, which creates a gap in service delivery (Public Service Commission 2014:02).

Leadership characteristics are essential for the leaders as they must have the ability to make change happen. These are defined as the qualities that are essential to ensure that leaders achieve a fine balance between traits, abilities, behaviours, sources of power and aspects of the situation. These characteristics become the determining factor of the ability of leaders to influence followers and accomplish group objectives. Leadership characteristics assist leaders to begin with the end in mind and to formulate an idea and then work through that idea to commit every thought, feeling and emotion (Marilyn 2010:01).

Hambleton (2016:10), a political analyst, argued that although power has been given to local government leadership, the indication of a lack of good leadership characteristics creates the possibility of moving power away from local communities. The most lacking characteristic in local leadership is becoming a convenor and a place shaper for local services. The lack of effective communication between the councils and their citizens in England is a problem similar to what South African local government councils are facing currently.

James and Cox (2007:10) who stated that community members have to be more actively engaged by their leaders and that leadership must have certain skills to empower their respective communities defined the expected leadership characteristics of ward councillors in England. On the other hand, James and Cox (2007:11) added that leadership should not promise too much because they end up 'burning out' after failing to deliver.

The role of councillors in community development is widely recognised by James and Cox (2007:11), who stipulated that ward councillors must share their values with the community and that they should be skilled advocates for the community. Councillors should also be able to speak freely about issues affecting their communities and be able to make informed decisions. In the case of Uganda, Asimo (2016:02) highlighted that local council leaders (councillors) are a link between the grassroots and national leadership levels. Asimo (2016:02) further acknowledged that their duties, as stipulated in the 1997 Local Government Act (as amended) of Uganda, include to legislate, consult with citizens on their development needs and possible solutions, and monitor government-funded development programmes. This is based on the understanding that a councillor is elected to serve the constituency, and the councillor therefore relates better to the needs of the society because they are better positioned to make decisions on behalf of the people. This is the main ideology behind a decentralisation policy.

Nkwana (2012:155) argued that the local government is the most important government level amongst the three government levels, namely, the national, provincial and local government. All citizens in all countries rely on getting services at the local government level because it is the government closest to the people and is regarded as the face of service delivery. As reported by the South African Local Government Association (2016:12), municipal councillors have to provide an effective leadership role for the municipality in order to strengthen service delivery and to economically guide the municipality in day-to-day activities. The legislative framework contains the leadership developments of ward councillors in the municipality. It is more important to make or suggest relevant recommendations to assist ward councillors to work more effectively towards achieving community objectives. Local leadership is also important because the development of communities in a local government rely mostly on the ward councillors (Paradza, Mokwena \& Richards 2010:06). Therefore, it is imperative for ward councillors to have good leadership skills and possess the required leadership characteristics.

Overall, all countries need good leadership characteristics for the effective well-being of the local citizens through sustainable local economic development. After all, the Handbook for Municipal Councillors indicates the broad mandate of local government officials as the one promoting developmental local government and facilitating socioeconomic development at the local municipal level (Paradza et al. 2010:08). 
In South Africa, party politics has played a significant role in how councillors are being elected to represent their communities, irrespective of the democratic processes the community prefers. The political and electoral systems in South Africa are democratic systems, but community members do not have an influence on who the political party decides to deploy to power because citizens vote for the party and not for the individuals. The South African electoral system of voting for a party and not directly voting for an individual favours the political party's leadership because the political party leadership can decide to deploy, recall and redeploy at any time without the approval of voters. The community members, the voters, feel betrayed by the system because they have no control over the behaviour of the people they have voted for. In the South African electoral system, half of the councillors in the municipality are elected through a proportional representation ballot, and the other half of the councillors are elected as ward councillors by residents in each ward (Helen Suzman Foundation 2014:15). This particular electoral system deprives community members of electing their own preferred candidates to represent them because the political parties use a different system of electing people, one that will represent the interests of the political party and the community votes for the candidate that has been endorsed by the party. The community does not have a chance to ascertain the leadership ability of the deployed person which creates a communication gap (Education and Training Unit 2011:09).

Service delivery remains one of the most important aspects that affect many communities in the country. The services provided to communities do not meet the prescribed requirements of the municipal documents, including the White Paper on Transformation of Service Delivery (Thornhill \& Dlamini 2012:41). The first port of call is the leadership characteristics of local leaders like councillors, who are there to ensure that their communities are well serviced and that the desires and aspirations of the populace are attended to. It is acknowledged that councillors are not directly involved in service delivery. However, they play a critical role as the interface between residents and the municipal administration. Research has shown that in local areas where councillors effectively and openly oversee municipal progress and constantly update their subjects, residents appear to be more satisfied with service delivery or have an understanding of the challenges the municipality is facing (Paradza et al. 2010:03). This has an overall effect of low protests and a very active citizenry engagement. Effective communication skill is a key characteristic that all councillors should possess. Furthermore, if councillors are active and effective, municipal administration realises that they can be held to account and thus improve their services to the residents.

Public service delivery protests in South Africa have been associated with a lack of adequate skills and competencies from the authorities to take firm decisions (De Wet 2017:04). Public protests have been prolonged and have escalated into a situation that cannot be controlled and which becomes more violent because of limited leadership skills of ward councillors to handle the situation. Burger (2009:155) argued that the primary reason for public protests is dissatisfaction with the service delivery of basic municipal services, such as running water, electricity and toilets (especially in the informal settlements); poor infrastructure; and a lack of houses. The sociopolitical instability has played a significant role in the contradictions between councillors and the municipality. The politicians, who will be appointed after the elections, including the ward councillors, need to take the responsibility for the promises they make and the expectations they create. The problem of fulfilling promises could arise because of lack of experience, low literacy levels of ward councillors and their unwillingness to work for the communities that elected them.

A study conducted by the ISS (ISS 2014:15) showed that the public protests in many communities across South Africa are related to the leadership of ward councillors, especially concerning their leadership characteristics and their role in service delivery. The ISS recorded that two-thirds of protests have been violent and mainly in the metropolitan areas. Public protests have the potential of turning into a revolution as this problem is linked with the frustrations of empty promises of service delivery or the failure of ward councillors to provide an effective leadership role (Hough 2008:08). An understanding of how to utilise the available resources at their disposal also plays a major role in service delivery. eThekwini Municipality has been a victim of serious public protests in the past whereby community members even decided to close big national roads in the eThekwini Municipality, such as the N2. The residents blockaded the N2 highway by burning tyres while demonstrating over a number of housing issues (Mthethwa 2015:01).

\section{Leadership challenges at the local government level}

The Collins English Dictionary (2013:19) clearly defines leadership as an activity that is applied by an individual who is categorised as the leader. A leader is regarded as the person who has the authority to make decisions on behalf of other people and show the direction that has to be followed. On the contrary, Reh (2016:05) argues that leadership is the timeless practice in such a way that a leader becomes a leader even if the person is no longer given a leadership responsibility within a group or party. Leaders are different from the general people because of the situations and conditions that require someone to take the leadership responsibility. Leaders have a vision to advance the interests of other people and have plans in place to address challenges.

Jooste (2016:25) discovered that leadership is a complex phenomenon that cannot be compared with any activities. Further arguments on leadership are directed towards political leaders who have a certain responsibility to guide and protect the interests of the society as a whole regardless of the preferred political parties by the community. 
The eThekwini Metropolitan Municipality is not an exception to what is expected from the political leaders, especially ward councillors, as the first level of the government which is closer to the people or community. Leadership skills and leadership qualities are very important for the local leaders to avoid conflict within the community itself and the conflict between the ward councillor and the community.

The key concepts provide reviews conducted on various theories and empirical literature related to public management, leadership and leadership characteristics. The theoretical study and empirical studies are used to provide more clarity and discuss the leadership characteristics and challenges facing local government leadership. The reviewed literature summarises the overall challenges that the country has with regard to leadership characteristics and includes the situation in other countries. Leaders think differently, not like the general population, and find solutions to problems before any damage. Leaders have to address certain questions, such as 'what is leadership?', 'why is it considered a difficult task?', 'how does an individual become a successful leader?' and 'what are the characteristics that build a successful leader?'.

Leadership challenges have not been a South African problem only. This is a problem that many countries in the world are facing. However, Africa has been a historical victim of lacking good leadership characteristics from its leaders. Poncian and Mgaya (2015:111) argued that many leaders in African countries, and particularly at local government levels, acted based on public opinions rather than on planned programmes to improve the living conditions of society. African leaders in democratic governments are trying to emulate Western governance models instead of learning from what African leaders in the pre-colonial period did.

The rise in the population rate in Africa has been viewed as one of the reasons that African leaders fail to provide clear leadership direction to advance the interests of the people. Lagging political and institutional reforms have been characterised by political fragmentation, recurring conflicts and authoritarian rule that have affected the development of democratic institutions and economic reform. Everyone in society belongs to the local government level and a rise in the population becomes a direct burden for the ward councillors because people expect the supply of service delivery from ward councillors (Abed \& Davoodi 2003:08). Local government leaders have also failed to reduce the rate of domestic violence in many communities. Furthermore, and because of these problems, a large percentage of people decided to migrate from their original homes and move to urban areas and live in the slums, with some living on the streets (Statistics South Africa 2011:12).

\section{Leadership characteristics}

Spears (2010:26-29) stated that the leadership role should be given to people who are servant leaders and that it begins with a natural feeling of passion to serve people.
Spears (2010:27) further emphasised some of the relevant and important leadership characteristics, which include listening, empathy, awareness, persuasion, conceptualisation, foresight, stewardship, commitment to the growth of people and building the community. These leadership characteristics must embrace and complement each other in order to bring about effective service delivery.

There are a number of leadership characteristics needed by councillors to fulfil the mandate given to them by communities. However, the following characteristics are perceived as key characteristics:

- Listening to and involving the local communities Councillors need to be in touch with all parts of their community.

- Building vision and direction - Effective community leadership involves securing the commitment of partners to deliver a shared vision for their area and also to shape it in the right direction.

- Working effectively in partnerships.

- Making things happen - Community leadership involves more than having a sense of direction.

- Standing up for communities - Local people want to know that the people they elected are standing up for them.

- Empowering local communities-Councillors must create an environment in which other leadership roles can develop and foster the development of active human beings and local communities.

- Accountability to communities - The local leadership always has to be accountable to the local citizens for any action taken or not taken.

- Using community resources effectively - Communities, councils and partners have a wide range of resources. It is therefore expected that all public resources are used effectively at all times, without any favour or any delays.

Paradza et al. (2010:12) outlined the clear role of ward councillors in the community and specified that ward councillors are the link between the community and the municipality and that their task is to ensure that the community participates in council programmes. They also facilitate community participation in municipal policymaking. Participation in policy-making depends on the experience and personal attributes of ward councillors to mobilise community members to participate. The public protests regarding service delivery in South Africa have been a problem for many years. Many previous researchers, such as Mileham (2009:66), did not focus on the potential and capabilities of ward councillors, and instead mainly focussed on the processes and training of councillors after they have been elected.

\section{Theoretical frameworks}

The theoretical underpinnings of this study have been derived from different leadership theories articulated by various researchers and authors, such as trait leadership theory, 
situational leadership theory, servant leadership theory and action-centred leadership theory. Trait leadership is described by Bolden e al. (2003:26) as a way of identifying the key characteristics of successful leaders, which is the focus of this study, and thus this theory has been considered significant for this article. On the other hand, situational leadership theory is articulated by McCleskey (2014:118) who argued that the theory requires a rational understanding of the situation and a suitable or appropriate response rather than a charismatic leader with a large group of dedicated and loyal followers who hardly ask questions about the leadership. This theory applies well to the South African context where residents get into the streets to demonstrate for poor service delivery or anything they are not happy about regarding the leadership. This is a way of holding leadership to account. Hodgetts (1993:278) posited that many researchers have tried to pinpoint the key factors that contribute to effective leadership and they concluded with the idea that if leaders possess superior qualities that differentiate them from followers, discovering these qualities would be easy.

\section{Research methodology}

Lichbach (1998:403) defined the world as a planet that has factual and counter-factual constraints and constructs. It is therefore important that the methodological issues are taken into serious consideration because inappropriate or irrelevant methodological choices will lead to wrong conclusions, and incorrect recommendations will also be made (Geddes 2003:18). On the other hand, Holden and Lynch (2004:02) viewed research methodology as a system that is a consequence of the methodological choice that has been made to collect the information during the study. O'Leary (2004:85) argued that the research methodology should serve as the framework that guides the set of paradigmatic assumptions. The information collected can be viewed as facts and it can also be tested.

This study has adopted a case study and mixed-method (qualitative and quantitative data; collected from two sources, ward councillors and community members, analysed accordingly qualitatively and quantitatively) approach because the case study which is defined as a method of enquiry is primarily designed to bring out the information from the viewpoint or understanding of the participants. Multiple sources were used for this study, such as real-life events, observation of the behaviour of ward councillors in eThekwini Metropolitan Municipality programmes and the behaviour of ward councillors towards the community members. For robustness triangulation of data sources, ward councillors and community members were used to generate primary data; on the other hand, secondary data in the form of statistics report in the literature regarding variables such as the number of service delivery protests were used. The mentioned sources were used to ensure that reliability is increased (Tellis 1997:44).

\section{Sample or target population}

The population of this study comprised 110 ward councillors in the eThekwini Municipality (Statistics South Africa 2018) and all households in those wards. The study focussed on only one municipality as a case study, with a total of 110 wards; then a sample as outlined below was drawn from this population. The focus of the study was to survey the ward councillors to profile their demographics and leadership characteristics, as well as their views on service delivery. On the other hand, the study surveyed the community and solicited their views and rating of performance of ward councillors (based on service delivery) and their overall leadership characteristics. A sampling size table developed by Krejcie and Morgan (2011:607-610) was used to determine that 86 participants would be an appropriate sample size for this study, using the following formula: $n=X * N * P *(1-P) /$ $M E 2 *(N-1)+(X 2 * P *(1-P)$.

where $N$ is the sample size; $X^{2}$ is the square for the specified confidence, population proportional; and ME is the desired margin error. Conducting a study of all 110 ward councillors in eThekwini Metropolitan Municipality was not feasible for this study because of the limited time frame and resources of the researcher. All wards in eThekwini Municipality were chronologically listed in Microsoft Excel, using ward numbers. Excel's random selection functions were used to randomly select the 86 wards that were visited. For community members, a convenience sampling technique was used, targeting at least three community members per ward in 10 randomly selected wards from the 86 wards.

A stratified sampling approach was used to survey community members, with at least three community members selected per ward. This gave a total of 30 respondents to whom the questionnaire was administered in 10 randomly selected wards. A total of 86 questionnaires were successfully completed by ward councillors and 30 by community members. A 100\% response rate was achieved for the study, for instruments to both councillors and community members. This response rate is excellent and has the potential to provide effective results. Fincham (2008:01) suggested that the response rate in a survey should be at least $60 \%$ and above. The response rate of this study exceeded this recommendation.

\section{Measuring instrument}

Quantitative data collection techniques rely on instruments with predetermined response categories. The results produced are easily summarised, compared and generalised. Quantitative research is mainly concerned with testing the hypotheses derived from the theory. A variety of measuring instruments can be used in research, namely, questionnaires, interviews and observation (North Dakota Compass 2015:04). In this study, closed-ended questionnaires were used, with one designed specifically for each group of respondents, that is, councillors and community members. The questionnaires were basically the same, only different in terms of how the items (questions) were framed. An example is that the questionnaire for ward councillors would include items on their leadership experience, while the one for community asks their length of stay in the particular ward. As the 
questions needed to be framed specifically for a particular group, separate questionnaires were opted for.

\section{Data analysis}

Data collected were cleaned, sorted, captured in SPSS and coded in preparation for analysis. The SPSS Statistical Package was used to analyse the data as it handles crosssectional data and categorical variables effectively. The analysis involved descriptive statistics in the form of frequency tables and charts, as well as inferential statistics in the form of chi-squared tests, $t$-tests, analysis of variance (ANOVA) and regression analysis, depending on the research questions being asked and the variables relevant to that question. The leadership characteristic scale was used to calculate the total score, with high scores signifying a better leader. The average of councillor self-rating and that of the community members was used to reduce recall bias (Northouse 2013:2778). Open-ended questions provided qualitative data that were analysed through themes, that is, thematic analysis. The results from qualitative data addresses the how and why questions not adequately covered by quantitative results.

\section{Data presentation, analysis and interpretation of results}

The results are based on the quantitative data gathered through the questionnaires. The presentation of the results is in two broad sections: one capturing the views of community members and the other capturing the views of local leaders themselves as per the surveys employed.

\section{Ward councillors}

\section{Gender}

The majority of the ward councillors $(70.9 \%)$ were male councillors, while female councillors constituted 29.1\%, which indicates that the gender balance in terms of the national government's equity is not properly implemented in the eThekwini Metropolitan Municipality.

\section{Age}

The majority of ward councillors (64\%) in eThekwini Metropolitan Municipality were above the age of 41 and not more than 59 years of age, which indicates that the youth in terms of creating continuity in the municipality is not properly considered.

\section{Highest level of education}

Completing the secondary level of education is considered as necessary in order to be able to read and write. Ward councillors also deal with many documents, and matriculation education is necessary for them to be able to read and write. Only $47.7 \%$ of ward councillors had completed their matriculation and did not have access to tertiary education, while $22.1 \%$ of ward councillors managed to complete their national diplomas in different fields; $11.6 \%$ stated that they have bachelor degrees, and $4.7 \%$ had completed postgraduate qualifications. Only $7 \%$ of ward councillors in eThekwini Metropolitan Municipality did not complete their secondary education and did not study any other short courses to equip themselves. This negatively affects understanding the policies of government and also fully participating in the drafting of municipal by-laws.

\section{Marital status}

Family structure is very important because it contributes to how leaders are respected by their communities. More than half $(53.5 \%)$ of the ward councillors who were part of the study were married. This is a symbol of being responsible in many communities' views, while $32.6 \%$ were not married.

\section{Numbers of dependents}

Ward councillors are not only leaders of the community but also leaders of their families. The majority of ward councillors stated that they have many family members dependent on them. Most of the ward councillors (37.2\%) had more than five dependants. Only $8.1 \%$ had only one dependant, which is the lowest percentage in terms of the dependants' level of the study.

\section{Breadwinner status}

The majority of ward councillors stated that they are breadwinners in their families and thus have a responsibility to support their families. A significant $68.6 \%$ were sole breadwinners, while $31.4 \%$ were not breadwinners. This means that many families depend on the ward councillors.

\section{Family members in leadership}

Many ward councillors who participated in the study were the first people to be in leadership positions in their families. However, there were ward councillors with family members who have been in leadership positions before. Ward councillors who shared leadership responsibilities with some family members comprised $17.4 \%$, while those who did not have family members in leadership positions comprised $80.2 \%$.

\section{Leadership positions of ward councillors' family members}

Some ward councillors (10.5\%) stated they have family members who are also ward councillors in different wards.

\section{Previous employment status}

Working experience contributes much in one's personal life because through this a person gets exposed to how to communicate with other people. The majority (84.9\%) of ward councillors stated that they have been employed previously, while $11.6 \%$ said they have never been employed before. Working experience is necessary because it improves the communication levels of leaders. 


\section{Type of employment}

Many ward councillors (31.4\%) were employed permanently in different sectors, including government institutions; $11.6 \%$ of ward councillors were casual workers who do not have job security. Being a ward councillor was the best option for them in terms of salary and job security. However, those who were permanent had left employment which had good job security for the purposes of leading the community.

\section{Reasons for terminating employment}

A majority (51.2\%) of ward councillors had resigned from their employment with the purposes of ensuring that they work full-time as ward councillors. Only 1.2\% had retired. However, if an individual has retired from a full-time job because of age, it becomes complicated for that particular individual to work full-time as a ward councillor and perform all activities or duties extremely well.

Table 1 shows the frequencies for each of the leadership characteristics items in the questionnaire, displaying the count and percentages per row for each category of the responses. It can be seen that all items, except perceptive and empathic, have majority of responses rating 'strongly agree'. This implies that the ward councillors believe they possess these qualities they are strongly agreeing to. In addition, the association between each item and the number of service delivery protests witnessed has been investigated using Pearson's chi-squared test to ascertain whether the relationship exists, and Somers' $d$ statistic to determine the strength and direction of the relationship. Relationships that are statistically significant are denoted by *. The results show that being articulate, selfconfident, persistent, outgoing, trustworthy and conscientious reduces service delivery protest (i.e. it improves service delivery in general). On the other hand, perception is associated with poor service delivery.

The article further classified the leadership characteristics components using the multiple discriminant strategy, and the results are presented in Figure 1. The results show that there are two main dimensions: one that is internal and one that is focussed on others. From the data in Table 1 and Figure 1, it can be concluded that it is not one set of characteristics that get the job done well - rather, it is a combination of different leadership qualities.

To determine the effects of leadership characteristics on service delivery, we specified and estimated the likelihood of a reported protest being for service delivery instead of any other kind of protest. Each ward has witnessed a protest; however, some had experienced service delivery protests, and others had experienced protests of other reasons.

Variables controlled in the model include total leadership rating, gender, highest level of qualification, employment

TABLE 1: Distribution of leadership characteristics responses and association with service delivery.

\begin{tabular}{|c|c|c|c|c|c|c|c|c|}
\hline Responses & Count & $\begin{array}{l}\text { Strongly } \\
\text { disagree }\end{array}$ & Disagree & Neutral & Agree & $\begin{array}{l}\text { Strongly } \\
\text { agree }\end{array}$ & $\begin{array}{l}\text { Pearson's } \\
\text { chi-square }\end{array}$ & Somers' $d$ \\
\hline \multirow{2}{*}{$\begin{array}{l}\text { 1. Articulate: Communicates } \\
\text { effectively with others }\end{array}$} & $\mathrm{N}$ & 4 & 2 & 1 & 20 & 59 & $18.451 * *$ & $-0.127^{*}$ \\
\hline & $\%$ & 4.7 & 2.3 & 1.2 & 23.3 & 68.6 & & \\
\hline $\begin{array}{l}\text { 2. Perceptive: Is discerning and } \\
\text { insightful }\end{array}$ & $\%$ & 54.1 & 24.7 & 3.5 & 8.2 & 9.4 & & \\
\hline \multirow{2}{*}{$\begin{array}{l}\text { 3. Self-confident: Believes in himself or } \\
\text { herself and hisor her ability }\end{array}$} & $\mathrm{N}$ & 3 & 2 & 2 & 28 & 50 & $23.785 * *$ & $-0.192 *$ \\
\hline & $\%$ & 3.5 & 2.4 & 2.4 & 32.9 & 58.8 & & \\
\hline $\begin{array}{l}\text { 4. Self-assured: Is secure with self, } \\
\text { free of doubts }\end{array}$ & $\%$ & 4.7 & 1.2 & 3.5 & 33.7 & 57.0 & & \\
\hline \multirow{2}{*}{$\begin{array}{l}\text { 5. Persistent: Stays fixed on the } \\
\text { goals despite interference }\end{array}$} & $\mathrm{N}$ & 4 & 1 & 5 & 23 & 53 & $20.200 *$ & $-0.017 * *$ \\
\hline & $\%$ & 4.7 & 1.2 & 5.8 & 26.7 & 61.6 & & \\
\hline \multirow{2}{*}{$\begin{array}{l}\text { 6. Determined: Takes a firm stand, } \\
\text { acts with certainty }\end{array}$} & $\mathrm{N}$ & 3 & 2 & 1 & 21 & 58 & 14.564 & -0.011 \\
\hline & $\%$ & 3.5 & 2.4 & 1.2 & 24.7 & 68.2 & & \\
\hline \multirow{2}{*}{$\begin{array}{l}\text { 7. Trustworthy: Is authentic and } \\
\text { inspires confidence }\end{array}$} & $\mathrm{N}$ & 4 & 1 & 3 & 21 & 57 & $17.831 *$ & $-0.003^{*}$ \\
\hline & $\%$ & 4.7 & 1.2 & 3.5 & 24.4 & 66.3 & & \\
\hline $\begin{array}{l}\text { 8. Dependable: Is consistent and } \\
\text { reliable }\end{array}$ & $\%$ & 5.8 & 2.3 & 1.2 & 23.3 & 67.4 & & \\
\hline \multirow{2}{*}{$\begin{array}{l}\text { 9. Friendly: Shows kindness and } \\
\text { warmth }\end{array}$} & $\mathrm{N}$ & 6 & 0 & 1 & 18 & 61 & 8.396 & -0.018 \\
\hline & $\%$ & 7.0 & 0.0 & 1.2 & 20.9 & 70.9 & & \\
\hline \multirow{2}{*}{$\begin{array}{l}\text { 10. Outgoing: Talks freely, gets } \\
\text { along well with others }\end{array}$} & $\mathrm{N}$ & 6 & 1 & 4 & 17 & 57 & $-21.149 *$ & $0.106 *$ \\
\hline & $\%$ & 7.1 & 1.2 & 4.7 & 20.0 & 67.1 & & \\
\hline \multirow{2}{*}{$\begin{array}{l}\text { 11. Conscientious: Is thorough, } \\
\text { organised and controlled }\end{array}$} & $\mathrm{N}$ & 2 & 1 & 8 & 26 & 48 & $20.444 *$ & $-0.012 *$ \\
\hline & $\%$ & 2.4 & 1.2 & 9.4 & 30.6 & 56.5 & & \\
\hline \multirow{2}{*}{$\begin{array}{l}\text { 12. Diligent: Is persistent, } \\
\text { hardworking }\end{array}$} & $\mathrm{N}$ & 4 & 4 & 2 & 24 & 51 & 11.108 & -0.039 \\
\hline & $\%$ & 4.7 & 4.7 & 2.4 & 28.2 & 60.0 & & \\
\hline \multirow{2}{*}{$\begin{array}{l}\text { 13. Sensitive: Shows tolerance, is } \\
\text { tactful and sympathetic }\end{array}$} & $\mathrm{N}$ & 1 & 4 & 2 & 10 & 67 & 9.419 & -0.026 \\
\hline & $\%$ & 1.2 & 4.8 & 2.4 & 11.9 & 79.8 & & \\
\hline \multirow{2}{*}{$\begin{array}{l}\text { 14. Empathic: Understands others, } \\
\text { identifies with others }\end{array}$} & $\mathrm{N}$ & 59 & 17 & 1 & 2 & 6 & 14.622 & 0.165 \\
\hline & $\%$ & 69.4 & 20.0 & 1.2 & 2.4 & 7.1 & & \\
\hline
\end{tabular}

*, statistical significance at $5 \% ; * *$, statistical significance at $1 \%$. 
experience, leadership experience, ward councillor experience and leadership training, which all summarise leadership characteristics. The omnibus test also confirms the goodness of fit of the model specified, as the chi-squared test is statistically significant $(p=0.000<0.10)$.

As in linear regression, binary logistics have pseudo-Rs that display how much variation in the dependent variable is explained by the controlled explanatory variables. In this case, the pseudo- $\mathrm{R}^{2}$ range is between 0.40 and 0.56 , which is a relatively high explanatory power in a cross-sectional setup (survey data generally have a low variability factor) (Pallant 2014).

Table 2 presents the co-efficient of the model. The two important columns are the $p$-values (Sig. [significance]) and

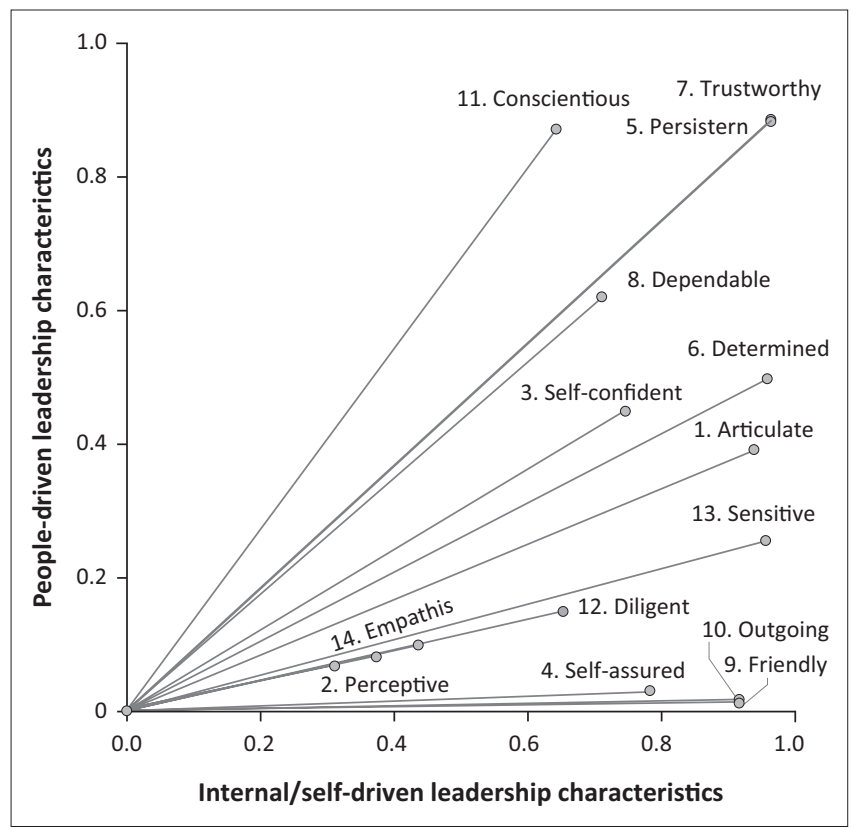

FIGURE 1: Classification of leadership characteristics. the $\operatorname{Exp}(\mathrm{B})$, which provide information on statistical significance and odds-likelihood ratios, respectively.

The results show that total leadership rating score (higher values showing positive or good leadership) reduces the occurrence of service delivery protest within communities. This implies that good leaders are able to communicate effectively with communities to the extent that even if service is delayed, the community will patiently wait for the service to be provided. Communication helps manage expectations of the communities and make them understand the challenges that the government will be facing.

On the other hand, regarding education, higher education of levels of ward councillor increases the chances of service delivery protests. Especially those with Grade 12 and those with diploma as highest qualification statistically significantly increase the likelihood of service delivery protest. This is supported by Bennis, Sample and Asghar (2015:34) who argued that not every great person is a leader and not every leader is a great person. They also emphasised that talent, skills or merit, intelligence, popularity and luck are not enough either. Furthermore, the combination of all these characteristics is also not enough. What is more important is to add the capacity to overcome failure. The ability to overcome or to process failure makes great leaders. The results show that (at $p<0.10$ ), Grade 12 level of education increases the odds of poor service delivery by 67.212 times compared to someone with no formal education (category 1). Furthermore, a diploma increases the odds of the protests in the ward being for service delivery by 204.872 times. In summary, high levels of education are associated with high probability of service delivery problems. It follows therefore that some ward councillors with no formal education are 'down-to-earth' (humble) and offer their services fully without regarding themselves highly.

The results further show that experience is indeed the best teacher. The more experienced a ward councillor is, as

TABLE 2: Variables in the regression equation.

\begin{tabular}{|c|c|c|c|c|c|c|}
\hline Step 1 & B & SE & Ward & df & Sig. & $\operatorname{Exp}(B)$ \\
\hline Total leadership rating & -0.042 & 0.046 & 3.834 & 1 & 0.036 & 0.959 \\
\hline Gender_Male & 1.083 & 1.008 & 1.154 & 1 & 0.283 & 2.952 \\
\hline No formal education & - & - & 15.034 & 5 & 0.010 & - \\
\hline Grade $1-8$ & 1.344 & 1.679 & 0.641 & 1 & 0.423 & 3.835 \\
\hline Grade 12 & 4.208 & 2.221 & 3.590 & 1 & 0.058 & 67.212 \\
\hline Certificate & 0.467 & 1.715 & 0.074 & 1 & 0.785 & 1.595 \\
\hline Diploma & 5.322 & 1.942 & 7.509 & 1 & 0.006 & 204.872 \\
\hline Degree & 1.974 & 1.939 & 1.036 & 1 & 0.309 & 7.199 \\
\hline Ever been employed_Yes & -0.662 & 1.025 & 0.416 & 1 & 0.519 & 0.516 \\
\hline Leadership years: Less than 1 year & - & - & 9.776 & 4 & 0.044 & - \\
\hline $1-2$ years & -1.021 & 2.035 & 0.252 & 1 & 0.616 & 0.360 \\
\hline $3-4$ years & -1.866 & 2.075 & 0.809 & 1 & 0.368 & 0.155 \\
\hline $5-6$ years & -5.351 & 2.002 & 7.148 & 1 & 0.008 & 0.005 \\
\hline More than 6 years & -3.967 & 1.559 & 6.475 & 1 & 0.011 & 0.019 \\
\hline Been councillor_Yes & 1.220 & 0.763 & 2.558 & 1 & 0.110 & 3.387 \\
\hline Community survey_Yes & 0.301 & 0.752 & 0.160 & 1 & 0.689 & 1.351 \\
\hline Constant & 18.317 & 40193.049 & 0.000 & 1 & 1.000 & 90127097.210 \\
\hline
\end{tabular}

Note: Values in bold indicate statistical significance at least at $5 \%$.

$\mathrm{SE}$, standard error; Sig., significance. 
measured by the number of years in such a position, the less likely the ward is facing service delivery-related problems (leadership years $p=0.044$ ). The statistically significant categories are the highest ones, namely, 5-6 years and more than 6 years.

Leadership rating, gender, attendance of leadership training, ever been a councillor before and conducting community survey do not statistically explain service delivery problems within eThekwini Municipality.

The next section presents results of the community survey conducted.

\section{Community members' data analysis}

This section presents the analysis for the rating on service delivery and leadership characteristics by community members. To be able to carry on with the inferential analysis, total scores for service delivery rating items and the leadership characteristics scale were computed. There were six questions on rating service delivery components, with a rating scale ranging from 1 to 5 (maximum). This implies that the minimum possible score is 6 , and the maximum possible score is 30 . The higher the score, the better the service delivery rating is by community members in that particular community. Given the nature of the score, a median will be more informative. A median of at least 18 would imply a good service delivery throughout.

For leadership characteristics, there were 14 items on the same rating scale as service delivery, meaning the minimum expected score is 14 and the maximum is 70 . A median of at least 42 reflects good leaders who can bring development to the community as they engage with communities with understanding, and they have the requisite skills.

The results in Table 3 show a median of 16, which is below the expected median of 18 , therefore indicating poor service delivery throughout. The expected minimum score for the service delivery is 6 and the maximum score is 30. The results show a minimum of 8 and a maximum of 26 in service delivery. This implies that service delivery is within the range of 18 for service delivery and does not indicate bad or good service delivery, but an average service delivery. With regard to leadership, the results show a median of 52, which implies that there are effective leaders who can ensure development in eThekwini Metropolitan Municipality and

TABLE 3: Rating of service delivery and leadership characteristics.

\begin{tabular}{lcc}
\hline Statistics & Service delivery & Leadership characteristics \\
\hline $\mathrm{N}$ & 30 & 30 \\
Mean & 15.6000 & 49.1000 \\
Median & 16.0000 & 52.0000 \\
Std. deviation & 4.61332 & 15.39223 \\
Range & 18.00 & 53.00 \\
Minimum & 8.00 & 17.00 \\
Maximum & 26.00 & 70.00 \\
\hline
\end{tabular}

Std., standard. who have exceeded the minimum median level of 42 . The expected minimum score for leadership characteristics is 14 and the expected maximum score is 70 . The results show that the minimum leadership characteristic is 17 and the maximum leadership characteristic is 70 , providing a range of 53, which indicates that the leadership characteristics in eThekwini Municipality are good. However, there are challenges and general problems within the municipality leadership.

\section{Descriptive statistics for community members' rating of service delivery and leadership characteristics}

The two computed variables were brought together using a regression variable plot (see Figure 2). The quadrants can be seen as classifying the wards in terms of service delivery and leadership characteristics of the councillors. The quadrant of interest is quadrant 1 (North-East), which represents high service delivery and high leadership characteristics. Wards $\mathrm{C}$, I and J have community members agreeing on the ranking of service delivery and leadership characteristics of their councillors. The lines creating quadrants represent the mean of each variable.

\section{Service delivery versus leadership characteristics}

It may be observed that Ward A members have scored below the service delivery average, and two below the leadership characteristic average score. Nkwana (2012:159) stated that leadership development programmes cannot be developed and consequently evaluated in isolation. The legislative frameworks and policies that are relevant to human resource development in local government have to be reflected upon. The impact of the political and administrative interface on leadership development of councillors in municipalities should be taken into account in order to contextualise effective leadership development of councillors in municipalities.

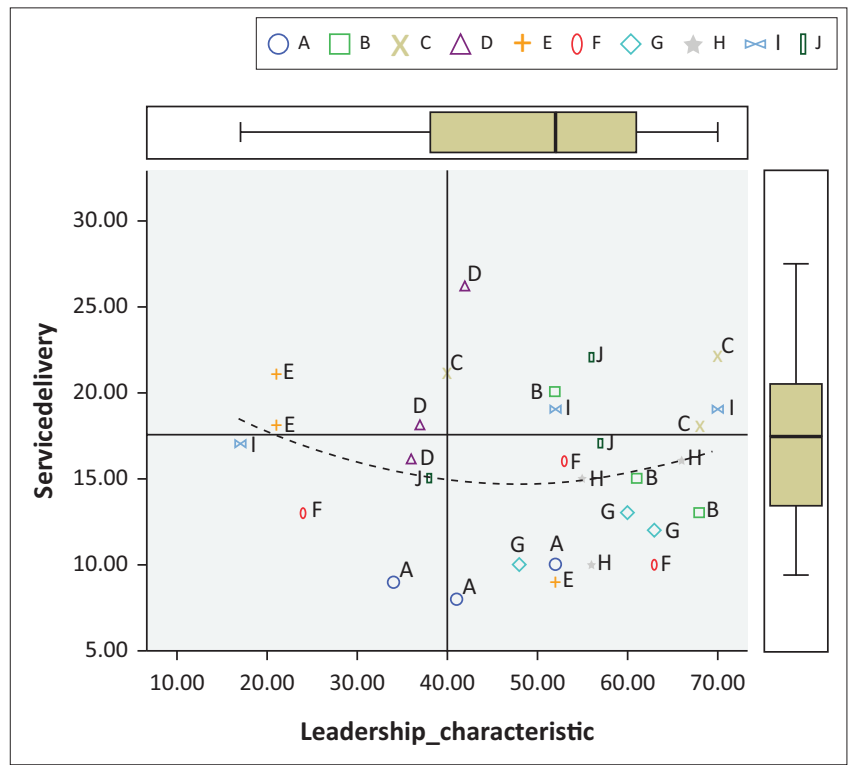

FIGURE 2: Service delivery versus leadership characteristics. 
Another example is wards $G$ and $H$, where the three community members agreed that service delivery is below average although leadership characteristics are very good. Leadership theories have identified techniques for determining the right leadership styles and characteristics and further identified that leadership characteristics and styles are influenced by the type of work that needs to be done, situational variables, the type of followers and the type of community that a councillor leads (Oracle White Paper 2012:07).

As shown in Figure 2, each letter represents a ward; therefore, if there are three letters in the quadrant box, this means that all three community members agreed with regard to rating on the variables - as is the case with wards $G$ and $H$. It should be noted that concentration is towards high leadership scores and is general around average service delivery. Shezi (2013:22) argued that service delivery to the community becomes easier and effective if political leadership has a good relationship with public officials who are working for state organs. Political leadership therefore finds it easier to play a leadership role and liaise with the community and the public officials in terms of the community developments and challenges, as well as to be able to address challenges during the implementation of public services.

Zvavahera (2013:02) stated that leadership is very important in all types or forms of organisations because without proper and effective leadership, the organisation stands a higher chance of failing or being effective. eThekwini Municipality is facing many challenges, including the relationship between ward councillors and community members. The study results indicate that the higher scores on leadership are equal to the higher score on the service delivery in a sense that leaders who possess good quality skills stand better chances of effectively delivering services to the community. The breakdown of the relationship between community members and ward councillors has negatively affected service delivery in many municipalities, including eThekwini Metropolitan Municipality.

The results concur with Spear's (2010: 26) theory of leadership, which identifies leadership characteristics as the natural feeling from the individual which has commitment to the growth of the people. Leadership characteristics have a direct influence on service delivery, and effective leadership skills increase the chances of good service delivery in the community.

According to Hays, DeVille and Mulhall (2000:376), it is very important to analyse the relationship amongst structural characteristics and measures of coalition and the effectiveness of the service delivery. Of interest to observe here is that the relationship between service delivery and leadership characteristics is ' $U$ '-shaped. At lower levels of leadership characteristics, the service delivery is high. This may be because of the ward councillors understanding their limitations and working hard to ensure that there is service delivery. However, as the leadership characteristics increase, there seems to be reluctance in pushing for service delivery. This is the point where a leader starts to take the community for granted, until again it reaches a point where the leader is mature enough to appreciate that leadership is being of service to the community. Then, the relationship becomes positive. Efforts to train and equip leaders with critical skills should target those with leadership scores that are around the mean point $A: B$, that is, the average leader. This is a point where the skills are good enough to lead but not enough to appreciate the service role bestowed upon one. In such instances if such leaders are identifiable, they can be trained to understand and appreciate their role, then become good leaders championing development.

\section{Recommendations}

Based on the findings of the empirical study in the previous section, the study findings show the importance of education level that is expected from ward councillors. Ward councillors need a tertiary education qualification in order to be fully literate and to understand municipal policies because they are entrusted with the making of local government policies. Education is a similar need because some people find that learning just opens more doors of an insatiable appetite to know and those who find pleasure in new ideas just keep discovering new ideas and that changes the character of the individual. Table 3 provides community responses whereby community members rated the leadership characteristics of ward councillors, which suggests that the ward councillors have a big challenge of possessing relevant leadership characteristics, which in turn affects service delivery. The ward councillors need to be trained not only in leadership but also in training that is based on character building and public participation skills programmes that will assist them to communicate effectively with community members. Anger management programmes are necessary for ward councillors because the study revealed that some ward councillors had anger issues with community members, which affected service delivery. In addition, a Municipality Integrity Committee is necessary to cross-check the characteristics and the background of the candidates who are vying for leadership position.

\section{Conclusion}

The aim of this study was to evaluate the leadership characteristics of ward councillors and to determine how such characteristics influence public service delivery in eThekwini Municipality. The aim of the study was carried out by examining the leadership characteristics of ward councillors in the eThekwini Municipality, identifying the factors that hinder ward councillors' leadership performance on their duties in the eThekwini Municipality, determining the impact of ward councillors' leadership skills on service delivery; and to suggest steps that can be followed to improve the leadership of ward councillors in the eThekwini Municipality.

Community members cannot easily embark on a public protest against a ward councillor that is transparent to the 
community because if there is a lack of service delivery or poor service delivery, the community members will know the actual challenges and the reasons for the lack of service delivery. Ward councillors of eThekwini Metropolitan Municipality lack a proper understanding of government policies and by-laws, which makes it difficult to make decisions that will improve service delivery. Almost 19\% of ward councillors of eThekwini Metropolitan Municipality find it difficult to understand the policies of government.

The high rate of service delivery protests in eThekwini Metropolitan Municipality is an indication that leaders are not providing effective leadership in terms of providing service delivery that is essential for the people and that ensures that people understand the shortfalls and challenges of the municipality. Approximately $54.4 \%$ of public service delivery protests have been experienced in the eThekwini Metropolitan Municipality.

Leadership characteristics have a direct relationship with service delivery, which clearly indicates that if leaders do not possess good and correct leadership characteristics, they cannot provide effective service delivery. eThekwini Metropolitan Municipality is the largest municipality in KwaZulu-Natal province and comprises 110 wards, and financial resources have been one of the most key delimitations on the study; however, another limitation was the availability of ward councillors and their understating of the research. Explanation was however provided extensively by the researcher before administering the instrument.

Ward councillors of eThekwini Metropolitan Municipality have been characterised by the community members as people who listen to the community members only before the elections. Immediately after the elections, the elected leaders become unavailable to community members. Ward councillors have a tendency of treating themselves as employees of the municipality who are only interested in receiving the remuneration for their work done instead of providing leadership without being motivated by the salary but being motivated by bringing a significant change to the lives of the people of eThekwini. The study recommends constant training of ward councillors on how to assess community needs and communicate to government, as well as how to communicate to people the plans by government. Integrated development plan requires constant check of service delivery progress to ascertain areas that need attention and therefore allocate resources.

\section{Acknowledgements}

The author (Z.M.) would like to thank the Durban University of Technology for providing him an opportunity to do his Master's degree in Public Administration. He would also like to thank the National Research Foundation, National Skills Fund and Beite Levensteen for their financial assistance towards the study.

\section{Competing interests}

The authors have declared that no competing interests exist.

\section{Authors' contributions}

Z.M. was the lead author who conceptualised the research problem and did the write-up. S.M. performed the data analysis. This article is an extract from the Master's dissertation of Z.M. at Durban University of Technology (DUT) supervised by S.M.

\section{Ethical considerations}

Ethical clearance was obtained from DUT (Ethical Clearance Number219/16FREC).

\section{Funding information}

This study was funded by the National Research Foundation, National Skills Fund and Beirtie Levensteen.

\section{Data availability statement}

Data sharing is not applicable to this article as no new data were created or analysed in this study.

\section{Disclaimer}

The views and opinions expressed in this article are those of the authors and do not necessarily reflect the official policy or position of any affiliated agency of the authors.

\section{References}

Abed, G.T. \& Davoodi, H.R., 2003, Corruption, structural reforms, and economic performance in the transition economies. In governance, corruption and economic performance, IMF, Washington, DC.

Afegbua, S.I. \& Adejuwon, K.D., 2012, 'The challenges of leadership and governance in Africa', International Journal of Academic Research in Business and Social Sciences 2(9), 141.

Asimo, N., 2016, 'Why citizens are catalyst to advance local governance: Effective local government requires competent leaders', Saturday Vision, July 25 , p. 2, viewed 25 July 2016, from http://www.newvision.co.ug/new vision/news/1424673/ citizens-catalyst-advance-local-governance.

Australian Gazzette, 2015, viewed 20 June 2018, from https://governmentgazette. sa.gov.au/gazettearchive?year month $\% 5$ Bvalue $\% 5 \mathrm{D} \% 5 \mathrm{Bmonth} \% 5 \mathrm{D}=12$ \&year month $\% 5$ Bvalue $\% 5 \mathrm{D} \% 5$ Byear $\% 5 \mathrm{D}=2015$.

Bennis, W., Sample, S.B. \& Asghar, R., 2015, The art and adventure of leadership: Understanding failure, resilience and success, John Wiley \& Sons, Hoboken, NJ.

Bolden, R., Gosling, J., Marturano, A. \& Dennison, P., 2003, A review of leadership theory and competency frameworks, viewed 22 January 2017, from http://www. leadership-theory-and-competency-framework.html.

Bratton, M., 2012, 'Citizen perceptions of local government responsiveness in subSaharan Africa', World Development 40(3), 516-527. https://doi.org/10.1016/j. worlddev.2011.07.003

Burger, M., 2009, 'Reflections on replicating Milgran', American Pyschological Association 64(1), 2027, viewed 11 August 2016, from https://www.burgeronleadership.com.

Collins English Dictionary, 2013, Definition of leadership, viewed 28 December 2016 from https://www.collinsdictionary.com/dictionary/english.

De Haas, M., 2016, 'The killing fields of KZN', South African Crime Quarterly 57(1), 43-53.

De Wet, P., 2017, 'Zuma must fall protests', Mail \& Guardian, June 11, p. 04, viewed 11 June 2016, from http://mg.co.za/data/2015-12-17-in-pictures-zumamustfallprotests.

Drennan, L.T., McConnell, A. \& Stark, A., 2014, Risk and crisis management in the public sector, Routledge, London.

Du Toit, A. \& Manganyi, N.C., 2016, Political violence and the struggle in South Africa, Springer, Palgrave Macmillan, United Kingdom.

Education and Training Unit (ETU) for Democracy, 2011, Local government election process in South Africa, viewed 30 July 2016, from http://www.etu.org.za/ toolbox/docs/govern/elections.html\#sytem.

Fincham, J.E., 2008, Response rates and responsiveness for surveys, standards and the journal, viewed 23 July 2017, from https://www.ncbi.nml.nih.gov/pmc/articles/ PMC2384218/. 
Geddes, B., 2003, Paradigms and sandcastles: Theory building and research design in contemporary politics, University of Michigan Press, Michigan.

Gender Development, 2017, Gender equality, viewed 12 September 2018, from https://www.oecd.org/dac/gender-development/1850708.pdf.

Gupta, V. \& Van Wart, M., 2015, Leadership across the globe, Routledge, London.

Hambleton, R., 2016, 'Can local leadership advance the cause of social inclusion?' paper presented at the European Urban Research Association Conference, Torino, Italy, 16-19 June, viewed 02 February 2017, from http://eprints.uwe. ac.uk/29954.

Hays, C.E., DeVille, J.O. \& Mulhall, P., 2000, Capacity for effectiveness the relationship between coalition structure and community impact, viewed 16 February 2018, from https://www.researchgate.net/publication/222800709 Capacity for_Effectiveness The Relationship_Between_Coalition_Structure_and_Community_Impact.

Hodgetts, R., 1993, Modern human relations at work, Dryden Press, Fort Worth.

Holden, M.T. \& Lynch, P., 2004, 'Choosing the appropriate methodology: Understanding research philosophy', Marketing Review 4(4), 397. https://doi.org/10.1362/146934 7042772428

Hough, M., 2008, 'Violent protests at local government in South Africa: Revolutionary potential', South African Journal of Military Studies 36(1), 1-13. https://doi. org/10.5787/36-1-41

Institute of Security Services Africa, 2014, What does increasing political violence mean for the future of South Africa? viewed 17 June 2016, from https://www. issafrica.org/iss-today/what-does-increasing-political-violence-mean-for-thefuture-of-south-africas-democracy.

James, S. \& Cox, E., 2007, Ward councillors and community leadership: A future perspective, Joseph Rowntree Foundation, New York.

Jooste, K., 2016, Leadership in health services management, 2nd edn., Juta and Company Ltd., Cape Town.

Krejcie, R.V. \& Morgan, D.W., 2011, Sample size table-research advisor, viewed 23 June 2016, from https://www.research-advisors.com/tools/SampleSize.htm.

Lichbach, M., 1998, 'Contending theories of contentious politics and the structureaction problem of social order', Annual Review of Political Science 1, 401-424. https://doi.org/10.1146/annurev.polisci.1.1.401

Marilyn, V.M.A., 2010, Characteristics of the effective leader, viewed 25 August 2017 from http://www.tnstate.edu/servicelearning/documents/Leadership $\% 20$ Characteristics.pdf.

McCleskey, J.A., 2014, 'Situational, transformational, and transactional leadership and leadership development', Journal of Business Studies Quarterly 5(4), and lead 130 .

Mileham, K., 2009, The role of a councillor, viewed 15 June 2016, from https:// kmileham.wordpress.com/2009/08/.../the-role-of-a-councillor/.

Morrell, R., Jewkes, R. \& Lindegger, G., 2012, 'Hegemonic masculinity/masculinities in South Africa: Culture, power, and gender politics', Men and Masculinities 15(1), 11-30. https://doi.org/10.1177/1097184X12438001

Mthethwa, T., 2015, Durban, public protests municipal meeting, viewed 30 July 2016 from http://www.sabc.co.za/news/a/84318380496d5f4c9d2ebffbc39efa26/ Durban-protest-prompts-municipal-meeting-20150810.

Nkwana, H.M., 2012, 'Leadership development for developmental local government', African Journal of Public Affairs 5(3), 155-166.
North Dakota Compass, 2015, Floristic quality assessment of one natural and three restored wetland complexes in North Dakota, USA, viewed 24 June 2017, from restored wetland complexes in North Dakota, USA, viewed 24 June 2017 , from
https://link.springer.com/content/pdf/10.1672/02775212\%282002\% $29022 \% 5 B$ https://link.springer.com/content/pd

Northouse, P.G., 2013, Leadership: Theory and practice, 6th edn., Sage, London.

O'Leary, Z., 2004, The essential research guide to doing research, Sage, London.

Oracle White Paper, 2012, Oracle's cloud solutions for public sector, viewed 20 June 2017, from http://www.oracle.com/us/industries/public-sector/cloud-solutionspublic-sector-wp-323002.pdf.

Pallant, J.P., 2014, Measuring the positive and negative aspects of the caring role in community versus aged care setting, viewed 20 May 2018, from https:// onlinelibrary.wiley.com/doi/abs/10.1111/ajag.12046.

Paradza, G., Mokwena, L. \& Richards, R., 2010, Assessing the role of councillors in service delivery at local government level in South Africa, Centre for Policy Studies, Johannesburg.

Poncian, J. \& Mgaya, E.S., 2015, Africa's leadership challenges in the 21st century: What can leaders learn from Africa's pre-colonial leadership and governance, viewed 20 July 2016, from https://papers.ssrn.com/sol3/papers.cfm?abstract id $=2623952$.

Public Service Commission (PSC), 2014, Report on the evaluation of performance and compliance with the Batho Pele Principles of Redress, viewed 26 January 2017, from www.psc.gov.za.

Reh, J., 2016, Types of leaders, viewed 29 December 2016, from https://www. thebalance.com/f-john-reh-2275040.

SALGA, 2016, Induction programme, viewed 29 July 2016, from http://www.SALGA. org.za/GTZ/Councillor-Induction-Program-Handbook-for-Municipal-Councillors.

Sharma, S. \& Rai, A., 2003, 'An assessment of the relationship between ISD leadership characteristics and IS innovation adoption in organizations', Information \& Management 40(5), 391-401. https://doi.org/10.1016/S03787206(02)00049-6

Shezi, L.G., 2013, Service delivery protests as a catalyst for development: The case of Ethekwini municipality, viewed 23 February 2017, from http://contentpro.seals. ac.za/iii/cpro/DigitalltemViewPage.external?lang=eng\&sp=1021095\&sp=T\&suite ac.za/
$=$ def.

Spears, L.C., 2010, 'Character and servant leadership: Ten characteristics of effective, caring leaders', The Journal of Virtues \& Leadership 1(1), 25-30.

Statistics South Africa (Stats SA), 2018, City of Cape Town, viewed 30 July 2018, from http://www.statssa.gov.za/?page_id=1021\&id=city-of-cape-town-municipality.

Statistics South Africa (Stats SA), 2011, City of Cape Town, viewed 30 July 2016, from http://www.statssa.gov.za/?page_id=1021\&id=city-of-cape-town-municipality.

Suzman, H., 2014, The South African electoral system, viewed 30 August 2016, from http://hsf.org.za/resource-centre/hsf-briefs/the-south-african-electoral-system.

Tellis, W., 1997, 'Application of a case study methodology', The Qualitative Report 3(3), $1-19$.

Thornhill, C. \& Dlamini, K., 2012, 'Councillor's role in service delivery: The case of Ekurhuleni Metropolitan Municipality', African Journal of Public Affairs 5(3), 36-53.

Zvavahera, P., 2014, An evaluation of the effectiveness of performance management systems on service delivery in the Zimbabwean civil service, viewed 20 July 2017 from https://pdfs.semanticscholar.org/6636/a75e2ac83bba548a40d250fffg ef86b87833.pdf. 